\title{
Bekasi Regency Workforce Readiness to Work in the Paperless Office
}

\author{
Fiya Fauha Umaima $1^{a^{*}}$, Erny Hutabarat $2^{\mathrm{b}}$ \\ ${ }^{a}$ Management Study Program, Faculty of Business, President University \\ ${ }^{\mathrm{b}}$ Management Study Program, Faculty of Business, President University \\ fiya.umaima@student.president.ac.id
}

\begin{abstract}
The increasing amount of paper consumption has an impact on the environment; forest (ecosystem and species), and pollution. On the other hand, the society shifts in the direction of green environment through the growth of Paperless Office world. The purpose of this research was to investigate how capable and available the workforce is to work in the Paperless Office with substitutes such as the digital mode in carrying out their duties. Quantitative methods were used with a population of Bekasi Regency people aged 17-64 years and the sample were 155 respondents. The data were analyzed using the SPSS v.22 tool and SEM-PLS method with SmartPLS 3.0 tool. The study found that environmental awareness did not have a significant influence on workforce readiness, where the higher the level did not influence Bekasi Regency workforce readiness to work at the Paperless Office. Meanwhile, digital competence and digital usage behaviour have been found to have a significant influence on the readiness of Bekasi Regency workforce to work at the Paperless Office.
\end{abstract}

Keywords: Environmental Awareness, Digital Competence, Digital Usage Behaviour, Workforce, Paperless Office

\section{Introduction}

Many environmental problems describe as affecting the environment's sustainability in Indonesia, including deforestation, air and water pollution, barren forest, etc., as stated by the Indonesia Environmental Observations Association (Ilmia, 2020). Indonesia's Industrial Law No. 3 years 2014 released by the Minister of Industry of the Republic of Indonesia, concerning industrial affairs stated in Article 3 part $\mathrm{C}$, as per the report, industry has many objectives and one of which is to become a green industry, which involves the implementation of a paperless office (Indonesia Ministry of Industry, 2020). The results of a survey conducted by Spire Research on 100 Indonesian companies in March 2015 stated that $40 \%$ of the companies surveyed indicated an increase in paper consumption in the last two years (Rosmainar, 2017). If the demand for paper continues to increase, it will result in deforestation slowly. This issue is a negative impact on the use of paper because the forest is one of the assets to survive (Yan, Zinda, \& Ke, 2020).

The efforts to save the earth can be started from a small scale, namely an area. In Bekasi Regency Regulation No.3, explain about the plans of Regional Long-Term Development (RPJPD) of Bekasi Regency in 2005-2025. It illustrates environmental problems in the Bekasi Regency Area that examining the condition of natural resources and the environment in the current Bekasi Regency, if not anticipated with the right policies and actions will be faced with the threat of food crisis, water crisis, and energy crisis (Samsudin, Bakar, \& Jusoh, 2020).

Based on Dorji's research (2018) found that the main factor in maintaining the function of the forest by increasing environmental awareness as the variables that influenced in applying the paperless office. In showing the level of environmental awareness of the workforce in Bekasi Regency, all people can see it from the amount of waste produced, especially the use of paper (Dorji, 2018). Based on National Waste Management Information System (2018), the composition of waste that occurs in Bekasi Regency is Paper as the second most. With the amount of $8.07 \%$ of the total waste available, the paper is one of the compositions that is expecting to continue to increase as is the piece of other garbage. Therefore, the environmental awareness of its inhabitants must protect the environment from pollution by going to the Paperless Office (Sangeetha \& K, 2020). 
Besides, according to the research conducted at the Institute of Local Government, it shows that the main factor is the lack of application of Paperless Office due to the lack of leaders in digital competence. Therefore, it is essential for the role of training for employees in improving digital capabilities (Papa, Dezi, \& Gregori, 2018). Seeing the problem to improve the digital competence of the workforce in Bekasi, the target of training participants for the workforce conducted by the government for electronic vocational training, the total only 176 participants in 2020. If compared to the total workforce population in Bekasi Regency, this shows only about $0.11 \%$ of efforts to improve the digital competence of the workforce in Bekasi Regency (Indonesia Ministry of Manpower, 2020).

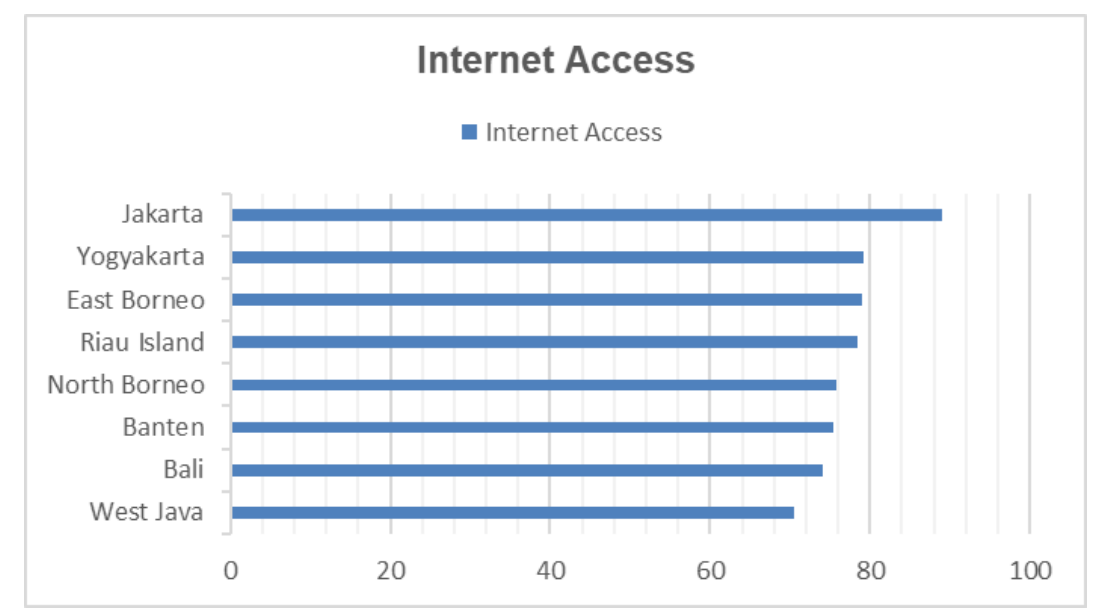

Figure 1. West Java Internet Access

Another factor shown by the research is that digital usage behaviour has an essential influence in the Paperless Office (Obeidat, 2015). The successful design of the digital workplace with management and user behaviour, based on Mohsen in 2019, offers more efficient ways of working, improves efficiency and increases employee engagement. To create support for the conduct of the digital use of a workforce, it takes the role of companies that support such Digital facilities like computer and Internet (Mohsen, Sharmin, \& Kirkland, 2019). There are the digital facilities to support digital usage behaviour can be a problem in Bekasi Regency. Based on Figure 1 shows data on the use of Internet access in West Java, including Bekasi is the lowest area compared to 7 other provinces in utilizing technology as a substitute for the paper (Directorate of Communication Statistics and Information Technology, 2018). If environmental awareness, digital competence, and digital usage behavior are improved as an effort to reduce paper use in Bekasi Regency, it can help save the earth from deforested forests, landslides, lack of oxygen, and lack of water in Indonesia.

The workforce is supposed to be inspired by the findings of this study to plan a variety of items needed to work in the Paperless Workplace, as the research will produce several factors. Besides, this research can also be an evaluation for the Bekasi Regency Government to create a workforce that is superior and highly competitive in keeping with the changing times. With a workforce that has prepared itself for work and is assisted by government efforts to prepare the workforce, the Bekasi Regency will have an environment that is maintained and easily adapted to technological developments because it has implemented the Paperless Office.

\section{Literature Review}

Workforce

Workforce is a population that has entered the working age, both those who have worked, not yet worked, or are looking for work. According to Indonesian government 
regulations, residents who have entered working age are those who are at least 17 years old to 64 years old (Bowen \& Finegan, 2015).

\section{Paperless Office}

In general, a paperless office can be defined as reducing or even eliminating paper consumption for office needs, including the government system (Shah, Amjed, \& Alkathiri, 2019). As is well known, the use of paperless office brings various benefits. One of them talked about the accessibility of documents. Moreover, the digital era supported by devices at hand, people no longer need to bother coming to the office complex to take care of something. Now with an all-electronic system, distance biases can be overcome (Dorji, 2018).

\section{Environmental Awareness}

The environment blends the physical conditions of natural resources, such as soil, water, solar energy, minerals, flora and fauna developing on land and in the ocean, with imaginative human institutions such as decisions regarding the use of the physical environment (Cubbage, O'Laughlin, \& Peterson, 2016). Knowledge of the importance of preserving the world that surrounds us is an important feature which everybody must-have. Considering the earth's condition that the temperature continues to rise, the residents as well as users of the natural resources that exist on this planet, protect our world so that the condition of the earth that improve (Sangeetha \& K, 2020). Thus, the first hypothesis for this study of these variables is: $\mathrm{H} 1$ : There is a significant influence of environmental awareness on workforce readiness to work in the Paperless Office.

\section{Digital Competence}

Digital Competence requires certain expertise with which is interdisciplinary in nature. Critical thinking, problem-solving, and computational thinking as three sets of skills that individuals need to master in order to become Digital Literacy or 21 st Century Skills. By covered in Learning and Innovation Skills, the people must also be able to practice creativity and innovation, think critically in problem-solving, and communication and collaboration skills (Ridsdale, Rothwell, \& Smit, 2015). Then, the researchers predict that the hypothesis for this variable is:

$\mathrm{H} 2$ : There is a significant influence of digital competence on workforce readiness to work in the Paperless Office.

\section{Digital Usage Behavior}

One theory of attitude and behaviour from Triandis 1971 states that the use of information technology, especially personal computers (PCs: Personal computers) by workers who have knowledge of the environment that can choose (optional), will be influenced by individual feelings (affect) on the use of PCs (Kurisu, 2015). Another theory related to digital use is the Theory of Uses and Gratification. This theory is called the theory of use and fulfilment of needs (Ahad \& Anshari, 2017). An explanation of this theory is each individual as a role holder in determining the selection of messages and the media. The activeness of the individual in choosing the desired media causes the need for information will clearly be fulfilled (Ashrafi, Habiba, \& Alam, 2020). Therefore, the researcher wants to investigate the results of this study whether or not they are similar to the results of previous studies. Thus, the hypothesis for this variable is:

H3: There is a significant influence of digital usage behaviour on workforce readiness to work in the Paperless Office. 


\section{Workforce Readiness}

Work readiness is a state that demonstrates a balance between physical, mental maturity and experience so that individuals can perform such work-related activities. Work readiness is the willingness of a person to complete a job in compliance with the requirements without encountering difficulties and challenges with set goals achieving optimum performance. Work readiness is a state of mental maturity that occurs in the workforce so they can carry out those work-related tasks or behaviours (Fagerholm, Ikonen, \& Kettunen, 2015).

Independent Variables

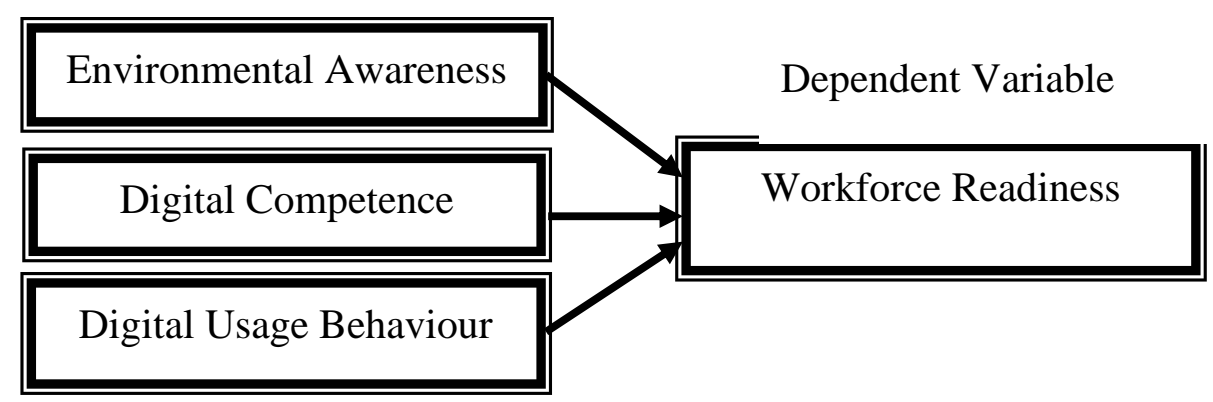

Figure 2. Theoritical Framework

Figure 2 shows the influence of three independent variables, which are environmental awareness, digital competence and digital usage behaviour on workforce readiness to work in the paperless office. Then, these three independent variables combined into one to know the influence simultaneously towards the dependent variable.

There have been many studies that discuss the Paperless Office or Digital Workplace. However, each study has its characteristics regarding this theme. There are the factors that influence, obstacles in implementation, the cause of failure, etc. Therefore, there are several new aspects of this research that have not been done in previous research. Among others are:

1. Area Aspect

Based on the results of reviewing several previous studies, no research has been found in Bekasi Regency regarding the application of the Paperless Office to the readiness of its workforce. What becomes most of their study is a company or an institution, not an area or region. It has become a new product produced by this research which is a research novelty.

2. Process Aspect

This research was carried out during the COVID-19 pandemic. This pandemic is a coronavirus spreading event in various regions for the first time. It affects the research process, which must keep a distance so as not to be affected by the virus - starting from collecting problem data, research data, and consulting with an advisor. It is all done remotely or online. Therefore, the research process carried out by following the health protocol from the government becomes a new thing and has never been done by previous studies.

\section{Variable Aspect}

In this study, the three independent variables (Environmental Awareness, Digital Competence and Digital Usage Behavior) are combined into one research and have hypothesis that influence the dependent variable (Workforce Readiness). It has never been done by previous studies, where there is only one independent variable to the dependent variable in each of the previous studies. 


\section{Method}

In this study, quantitative research methods are used because they want to make predictions and test hypotheses. Quantitative analysis is a knowledge discovery technique that uses data in the form of numbers to interpret information about the purpose of the investigation. Therefore, the required data are in the way of amount. Quantitative research will result in a considerable sample size representing the population within the scope of the area chosen (Sugiyono, 2017).

\section{Scope}

The scope of this research only explores workforce readiness to work in a paperless office with an analysis of the workforce's environmental awareness, digital competence, and digital usage behaviour.

\section{Limitation}

The research conducted to investigate the readiness of the Bekasi Regency workforce to work in the paperless office by analyzing the sample of the population who meet the criteria as the workforce in Bekasi Regency. The limitation of the criteria in this study is those of working age 17-64 years and residing only in Bekasi Regency.

\section{Data collection}

In this study, the data source used is primary data. As the first primary data collection technique, data were collected based on a questionnaire distributed through 155 respondents as sample from Bekasi Regency has 157,991 workforces. The questionnaire as a data collection technique and the respondents, fill their identity as the first step. If the respondent does not meet several requirements, then the respondent cannot continue to the next step. The respondents filled out the answers to their questionnaire using a Likert Scale. The level of approval referred to in this Likert Scale consist of 5 choice scales that have gradations from Strongly Disagree (SD) to Strongly Agree (SA) (Hermawan \& Amirullah, Quantitative \& Qualitative Approaches to Business Research Methods, 2016).

\section{Data Analysis}

The data analysis method in this study uses SEM. Structural Equation Modeling (SEM) is a statistical technique capable of analyzing patterns of relationships between latent constructs and indicators, latent constructs with each other and direct errors in measurement. Besides, this study uses the Partial Least Square (PLS) method and is assisted with SmartPLS 3.0 data processing tools. PLS can be an approach to structural modelling that shows the relationship between hypothesized constructs (Haryono, 2016).

The respondents filled out the answers to their questionnaire using a Likert Scale. Likert Scale is a research scale used to measuring the attitudes and perceptions. With this Likert Scale, respondents were asked to complete a questionnaire that required them to determine their agreement degree with a series of questions. The level of approval referred to in this Likert Scale consists of 5 choice scales that have gradations from Strongly Disagree (SD) to Strongly Agree (SA) (Hermawan \& Amirullah, Metode Penelitian Bisnis Pendekatan Kuantitatif \& Kualitatif, 2016). 


\section{Results and Discussions}

Measurement Model

Table 1. Measurement Model

\begin{tabular}{ccc}
\hline Variable & Items & Outer Loading \\
\hline Environmental Awareness & ENV4 & 0.878 \\
& ENV5 & 0.848 \\
Digital Competence & DC1 & 0.890 \\
& DC2 & 0.912 \\
\multirow{2}{*}{ Digital Usage Behaviour } & DC5 & 0.802 \\
& DUB1 & 0.718 \\
Workforce Readiness & DUB4 & 0.767 \\
& DUB9 & 0.820 \\
& WR2 & 0.748 \\
& WR5 & 0.756 \\
& WR8 & 0.781 \\
\end{tabular}

Convergent validity is done by looking at the item reliability (validity indicator), which is indicated by the loading factor value. The loading factor value is greater than 0.7 , which is said to be valid. In this study, the loading factor limit used was 0.7 (Haryono, 2016). After processing the data using SmartPLS 3.0, the results of the loading factor can be shown, as shown in the Table 1.

For discriminant validity is done by looking at the cross-loading value of the construct measurement. A measurement model has good discriminant validity if the correlation between the construct and its indicator is higher than the correlation with indicators from other block constructs (Haryono, 2016). After processing the data using SmartPLS 3.0, the results of crossloading can be shown in the following table:

Table 2. Discriminant Validity

\begin{tabular}{ccccc}
\hline Digital Competence & $\begin{array}{c}\text { Digital Usage } \\
\text { Behaviour }\end{array}$ & $\begin{array}{c}\text { Environmental } \\
\text { Awareness }\end{array}$ & $\begin{array}{c}\text { Workforce } \\
\text { Readiness }\end{array}$ \\
\hline DC1 & $\mathbf{0 . 8 9 0}$ & 0.396 & 0.325 & 0.464 \\
DC2 & $\mathbf{0 . 9 1 2}$ & 0.402 & 0.301 & 0.500 \\
DC5 & $\mathbf{0 . 8 0 2}$ & 0.326 & 0.276 & 0.452 \\
DUB1 & 0.239 & $\mathbf{0 . 7 1 8}$ & 0.239 & 0.376 \\
DUB4 & 0.301 & $\mathbf{0 . 7 6 7}$ & 0.247 & 0.433 \\
DUB9 & 0.421 & $\mathbf{0 . 8 2 0}$ & 0.307 & 0.608 \\
ENV4 & 0.308 & 0.329 & $\mathbf{0 . 8 7 8}$ & 0.290 \\
ENV5 & 0.288 & 0.270 & $\mathbf{0 . 8 4 8}$ & 0.262 \\
WR2 & 0.405 & 0.496 & 0.299 & $\mathbf{0 . 7 4 8}$ \\
WR5 & 0.359 & 0.451 & 0.183 & $\mathbf{0 . 7 5 6}$ \\
WR8 & 0.495 & 0.436 & 0.230 & $\mathbf{0 . 7 8 1}$ \\
WR9 & 0.417 & 0.568 & 0.270 & $\mathbf{0 . 8 0 3}$ \\
\hline
\end{tabular}

From the cross-loading results in Table 2, it shows that the correlation value of the construct with the indicator is greater than the correlation value with other constructs. Thus, all latent constructs or variables have good discriminant validity, where the indicators in the construct indicator block are better than the indicators in other blocks.

The measurement model is measured not only by assessing convergent validity and discriminant validity but also by looking at the reliability of the construct or latent variables as measured by the composite reliability value. The construct is declared reliable if composite 
reliability has a value $>0.7$, then the construct is declared reliable (Haryono, 2016). The SmartPLS output results for the composite reliability value can be shown in Table 3:

Table 3. Composite Reliability

\begin{tabular}{lc}
\hline \multicolumn{1}{c}{ Variable } & Composite Reliability \\
\hline Environmental Awareness & 0.854 \\
Digital Competence & 0.902 \\
Digital Usage Behaviour & 0.813 \\
Workforce Readiness & 0.855 \\
\hline
\end{tabular}

From the Smart PLS output results in the table above, the composite reliability value for all constructs is above a value of 0.70 . With the resulting value, all constructs have good reliability in accordance with the required drinking value limits.

\section{Structural Model}

Analysis of Variant (R2) or Determination Test

Analysis of Variant (R2) or the Determination Test, which is to determine the influence of the independent variable on the dependent variable, the value of the coefficient of determination can be shown in the Table 4:

Table 4. Determination Test

\begin{tabular}{cc}
\hline Variable & $\mathbf{R}^{\mathbf{2}}$ \\
\hline Workforce Readiness & 0.493 \\
\hline
\end{tabular}

Based on the table above, environmental awareness, digital competence, and digital usage behaviour variables can explain the variability of the workforce readiness construct by 0.493 or $49.3 \%$. Thus, the value of R2 (0.493) is in the moderate category.

\section{Hypothesis Result}

Hypothesis testing is carried out based on the results of the Inner Model (structural model) test, which includes the r-square output, parameter coefficient and t-statistic. To see whether a hypothesis can be accepted or rejected, among others, by paying attention to the significance value between the constructs, t-statistics, and p-values. This research hypothesis testing was carried out with the help of SmartPLS (Partial Least Square) 3.0 software. These values can be seen from the bootstrapping results. The rule of thumb used in this study is tstatistic $>1.96$ with a significance level of p-value $0.05(5 \%)$ and a positive beta coefficient (Haryono, 2016).

Table 5. Hypothesis Testing

\begin{tabular}{|c|c|c|c|c|c|}
\hline & $\begin{array}{l}\text { Original Sample } \\
\qquad(\mathrm{O})\end{array}$ & $\begin{array}{l}\text { Sample Mean } \\
\text { (M) }\end{array}$ & $\begin{array}{c}\text { Standard } \\
\text { Deviation } \\
(\mathrm{STDEV})\end{array}$ & $\begin{array}{l}\text { T Statistics } \\
(|\mathrm{O} / \mathrm{STDEV}|)\end{array}$ & P Values \\
\hline $\begin{array}{l}\text { Environmental Awareness } \rightarrow \\
\text { Workforce Readiness }\end{array}$ & 0.042 & 0.044 & 0.073 & 0.574 & 0.566 \\
\hline $\begin{array}{l}\text { Digital Competence -> Workforce } \\
\text { Readiness }\end{array}$ & 0.321 & 0.323 & 0.068 & 5.130 & 0.000 \\
\hline $\begin{array}{l}\text { Digital Usage Behaviour -> } \\
\text { Workforce Readiness }\end{array}$ & 0.481 & 0.485 & 0.058 & 8.337 & 0.000 \\
\hline
\end{tabular}

The first hypothesis tests whether Environmental Awareness has a positive influence on Workforce Readiness. The test results show the beta coefficient value of Environmental Awareness to Workforce Readiness is 0.042 , and the t-statistic is 0.574 . From this result, it is stated that the t-statistic is not significant. Because $<1.96$ with $\mathrm{p}$-value $>0.05$, so the first 
hypothesis is rejected. This proves that Environmental Awareness is not proven to have a significant influence on Workforce Readiness.

The second hypothesis tests whether Digital Competence positively influences Workforce Readiness. The test results show that the beta coefficient of Digital Competence on Workforce Readiness is 0.321 , and the t-statistic is 5.130. From this result, it is stated that the t-statistic is significant. It shows $>1.96$ with $p$-value $<0.05$, the second hypothesis is accepted. This proves that Digital Competence is proven to have a significant influence on Workforce Readiness.

The third hypothesis tests whether Digital Usage Behaviour positively influences Workforce Readiness. The test results show that the beta coefficient value of Digital Usage Behaviour on Workforce Readiness is 0.481 , and the t-statistic is 8.337 . From this result, it is stated that the $t$-statistic is significant. Because $>1.96$ with $p$-value $<0.05$, so the third hypothesis is accepted. This proves that Digital Usage Behaviour is proven to have a significant influence on Workforce Readiness.

\section{Discussion}

The Influence of Environmental Awareness on Workforce Readiness

Based on the results of the hypothesis test, it proves that environmental awareness has a positive influence on the readiness of the workforce to work in the Paperless Office. Apart from that, the positive influence that was not given gave a significant result. This shows that even though the more the workforce has a high awareness of the environment, it does not mean the higher its readiness to embrace digital developments and efforts to reduce paper use to fulfil their work activities. This is supported by previous research, which states that there is a weak relationship with environmental awareness with the performance of employees who use digital (Amartha, Hamzah, \& Herdiansyah, 2019). If we return to the problem in Bekasi Regency, paper is still the second largest waste, which indicates that the environmental awareness of the community itself is still very low. As supported by another research the positive influence of environmental awareness is still an obstacle to the application of the Paperless Office, which is still very low for a sense of concern for the environment (Muhammad, 2020).

In the Environmental Awareness questionnaire, the statement about disposing of paper waste which is always in its place had the highest average value. It offers that many Bekasi Regency workforces in non-paperless office agree and have carried out activities to dispose of paper waste in its place after it is used and no longer used. Indirectly, a sense of awareness of protecting the environment by reducing paper waste in this area can be made if the community cares about it. It will help the government to create areas with good, clean and sustainable environments. Also, the lowest average was on their awareness of cleaning up the paper waste around them. Researchers assume that environmental awareness is still low starting from small things such as paper use management in non-paperless office. Where paper that has been used is still left alone without being cleaned or even recycled for use. It is supported by previous research, which shows that environmental awareness is still relatively low in the application of Paperless, one of which is due to the pattern of life (Millatuzzuhriyah, Rofiah, \& Zuhaida, 2019). Besides, it has differentiation with the research of Sangeetha \& Nagarajan (2020). The finding of this study is the knowledge of the majority of green human resource management employees are helpful in helping to increase employee organizational performance (Sangeetha \& K, 2020).

\section{The Influence of Digital Competence on Workforce Readiness}

Based on the research findings of the hypothesis test, it shows that digital competence has a positive influence on the workforce's readiness to work in the Paperless Workplace. Apart from that, the constructive impact that was offered provided a significant result. It shows that 
the more digital competence the workforce has, the higher its readiness to face digital technologies and attempts to reduce the use of paper to carry out its work activities. As this research has in common that a workforce that has digital capabilities has been successfully applied to increase productivity in smart offices (Mohsen, Sharmin, \& Kirkland, 2019). In addition, it is supported by another previous research that there is a successful influence on the development of soft skills technology for teachers in making e-Modules, where this process requires digitization and reduces paper use (Kumalasani, 2019).

The digital competence questionnaire states that the Bekasi Regency workforce effortlessly defines problems that occur when using digital devices. It shows that with the existence of digital tools, they find it helpful to solve the problem by starting to detect the problem. If it is related to the readiness of the Bekasi Regency workforce, its digital competence will help when working at the Paperless Office. Therefore, it is imperative to highlight that digital competence has an essential role in readiness to operate using digital.

However, it is different from Klassen's research (2019), which states that while more companies strive to digitize learning and knowledgebase information, the result is that some employees struggle to integrate emerging technology into their work habits, resulting in a reemergence of paper-based resources (Klassen, 2019). It is also the same other research that the analysis of the correlation between challenges and paperless acceptance, also concluded that challenges have a negative relation to paperless adoption (Dorji, 2018).

\section{The Influence of Digital Usage Behaviour on Workforce Readiness}

According to the hypothesis test research findings, it shows that digital usage behaviour has a positive influence on the readiness of the workforce to work in the Paperless Workplace. In addition, a significant result was the constructive influence that was being offered. It shows that the greater the workforce's digital usage behaviour, the greater its readiness to face digital technologies and attempts to reduce the use of paper to perform its work activities. These results seem to be supported by previous study, who stated that the truth about habits is very influencing. Therefore, it is necessary to have a significant positive habit in supporting the successful application of paperless concepts in an office (Zaenuri, Sudarmin, \& Utomo, 2017).

Based on the results of the questionnaire contained in the Digital Usage Behavior variable, there is a statement with an average which shows that the attitude which consists of the attitudes and thoughts of the user has an influence on their readiness to work in the Paperless Office. Another research found that for the successful implementation of digital applications, it is influenced by the perspective of the application user. It shows that the provision of digital facilities helps them to increase their use of technology. These facilities can be in the form of gadgets, laptops, internet, and other supporting digital devices. The facilities owned are believed to be able to increase digital capabilities through their habit of solving problems with the help of these digital devices. That way, their issues or tasks can be resolved both efficiently and effectively. As an indicator of digital usage behaviour, digital facilities need special attention if the government want to increase their workforce digital capabilities. So, the researcher 
concluded that if you want to apply the paperless concept with digital as a substitute and solution, then digital use is needed (Kimlin \& Idris, 2019).

Z Generation's Role

Based on the previous explanation, digital is very decisive in the application of a paperless office. Therefore, Z Generation or the Net Generation (iGeneration) supposed to be able to adapt to this situation. $Z$ Generation grew up in the digital era, so they were aware of technology and were familiar with advanced digital devices, since childhood. Indirectly, the technology that accompanies the growth and development of this $\mathrm{Z}$ Generation affects their personalities. $\mathrm{Z}$ Generation is also defined as a generation of influencers who are natives of the true digital era today. Because from birth to adulthood, this generation has been exposed to the internet, social networks and cellular systems. These technological developments have resulted in the generation of hyper cognitive that is more comfortable collecting cross-references from multiple sources of information and integrating virtual experiences with real-life. Z Generation can use technology as a campaign effort for environmental sustainability. They can start creating educational content, interesting content, content that supports the government's efforts to preserve the environment. This can indirectly foster a sense of concern for the environment for their followers on social media. (Linnes \& Metcalf, 2017).

\section{Conclusions and Recommendation}

Based on the elaboration of the analysis of this research regarding Bekasi Regency workforce readiness to work in the Paperless Office, it can be concluded that several important points. The environmental awareness was found to have no significant influence on workforce readiness to work in the Paperless Office. It means that the higher the degree of environmental awareness the workforce has, it cannot increase their readiness and ability to work in the Paperless Office. Otherwise, digital competence was found to have a significant influence on the readiness of workers to work in the Paperless Office. It means that the higher the level of digital competence that the workforce has can increase their readiness and ability to work in the Paperless Office. Besides that, digital usage behaviour was found to have a significant influence on the readiness of workers to work in the Paperless Office. It means that the higher the level of digital usage behaviour that the workforce has can increase their readiness and ability to work in the Paperless Office.

Seeing the results of this study, which show the digital competence as one of the important elements that affect the formation of employee readiness to work at the Paperless Office, there is a need for efforts to improve the ability of Bekasi people regarding digital competence. It can be done by increasing the quota of participants for digital training or the like because they see the potential of the Bekasi Regency which is getting longer, more developing and following the development of existing technology. In addition, researchers suggest the Indonesia government and international government provide assistances in the form of digital facilities such as internet connection and gadget funding assistance. However, as a basis, the government can add a learning curriculum for students in Indonesia to implement environmental awareness. It can shape the characteristics of the nation's next generation who are be able to adapt to the times, and still loving environmental sustainability. 
For companies that want to improve the quality of their employees' ability to use digital devices, they can provide complete digital devices such as computers, mice, internet networks, flash/hard disks, etc. It can provide performance efficiently and effectively, which indirectly affects company productivity. In addition, companies can be concerned about providing training as the development of employee competencies. Furthermore, each manager or supervisor around the world needs to control the work of his employees using digital devices for company evaluation, which can be corrected if any deficiencies are found. It can be implemented to other country.

Researchers suggest that further research for the object of research can be specified in the area. Because of the more specific, the more detailed the problem. In addition, further research can use qualitative research to be able to find out the reasons for the problem, so that it is more widely explained. Further research can also obtain data by interviewing the government or a company in dealing with this problem and how they are trying to solve it.

\section{References}

Ahad, A., \& Anshari, M. (2017). Smartphone Habits Among Youth: Uses and Gratification Theory. International Journal of Cyber Behavior, Psychology and Learning (IJCBPL), 7(1), 65-75.

Amartha, M. Y., Hamzah, U. S., \& Herdiansyah, H. (2019). Application of Environmental Awareness and Environmental. Journal of Physics: Conference Series.

Ashrafi, D. M., Habiba, W., \& Alam, I. (2020). An Assessment of the Behavioural Intention for Using Ride-Sharing Services: Empirical Evidence from a Developing Country. Malaysian Journal of Consumer and Family Economics Vol 24.

Bowen, W., \& Finegan, T. (2015). The Economics of Labor Force Participation. Princeton University Press.

Cubbage, F., O'Laughlin, J., \& Peterson, M. (2016). Natural Resource Policy. Waveland Press.

Directorate of Communication Statistics and Information Technology. (2018). Indonesian Telecommunication Statistics. Jakarta: BPS.

Dorji, T. (2018). Going Paperless Office. Royal Institute of Management, 17-18.

Fagerholm, F., Ikonen, M., \& Kettunen, P. (2015). Performance Alignment Work: How software Developers Experience the Continuous Adaptation of Team Performance in Lean and Agile Environments. Information and Software Technology, 64, 132-147.

Haryono, S. (2016). SEM method for management research with AMOS LISREL PLS. Bekasi: PT. Intermedia Personalia Utama.

Hermawan, S., \& Amirullah. (2016). Metode Penelitian Bisnis Pendekatan Kuantitatif \& Kualitatif.

Hermawan, S., \& Amirullah. (2016). Quantitative \& Qualitative Approaches to Business Research Methods.

Ilmia, A. D. (2020). The Influence of Green Human Resource Management Strategies Towards Job Atrraction of Millenial Workforce in JABODETABEK.

Indonesia Ministry of Industry. (2020). Law No. 3 of 2014 Concerning Industry.

Indonesia Ministry of Manpower. (2020, July 6). Bekasi Center for Job Training Development. Retrieved from Training Target: https://blkbekasi.kemnaker.go.id/pelatihan/target?tahun=2020\&kejuruan=58

Kimlin, H. B., \& Idris, S. I. (2019). Crea8tif: Smart Application for Digital Art Project Management. Journal on Technical and Vocational Education (JTVE), Vol 4 No 3: Special Edition NASCO.

Klassen, A. (2019). Deconstructing Paper-Lined Cubicles: Digital Literacy. International Journal of Advanced Corporate Learning (iJAC), 12(3), 5-13.

Kumalasani, M. P. (2019). Development of Learning Softskill Technology through Making eModules for Elementary School Teachers. Journal of Education and Basic Learning. 
Kurisu, K. (2015). Pro-Environmental Behaviors. Tokyo: Spinger Japan.

Linnes, C., \& Metcalf, B. (2017). iGeneration And Their Acceptance of Technology. International Journal of Management \& Information Systems, 15.

Millatuzzuhriyah, A., Rofiah, H. Q., \& Zuhaida, A. (2019). Analysis of Environmental Awareness Level in Natural Science Students in Applying Learning about Paperless at IAIN Salatiga.

Mohsen, Sharmin, \& Kirkland. (2019). The Need for Digital Workplace: Increasing Workforce.

Muhammad, G. (2020). Analysis and Strategy Proposal for Paperless Implementation Efforts in Administrative Processes (Case Study: Industrial Engineering Department). UIN Suska Riau.

Obeidat, M. A. (2015). Empirical Analysis for the Factors Affecting Realization of Paperless Office. International Journal of Economics, Commerce and Management.

Papa, A., Dezi, L., \& Gregori, G. (2018). Improving Innovation Performance Through Knowledge Acquisition: The Moderating Role of Employee Retention and Human Resource Management Practices. Journal of Knowledge Management.

Queirós, A., Faria, D., \& Almeida, F. (2017). Strengths and Limitations of Qualitative and Quantitative Research Methods. European Journal of Education Studies.

Ridsdale, C., Rothwell, J., \& Smit, M. (2015). Strategies and Best Practices for Data Literacy Education: Knowledge Synthesis Report.

Rosmainar, L. (2017). Journal of Review: Analysis of Alternative Processing Materials. Jurnal Inkofar Volume 1 No. 2, 2.

Samsudin, N., Bakar, E. A., \& Jusoh, Z. M. (2020). Personal and Environmental Determinants of Consumer Legal Literacy among Malaysian Consumers. Malaysian Journal of Consumer and Family Economics, Vol 25 (S1), 1.

Sangeetha, \& K, N. S. (2020). Employee Awareness on Green Human Resource Practices. UGC Care Journal.

Shah, I., Amjed, S., \& Alkathiri, N. (2019). The Economics of Paper Consumption in Offices. Journal of Business Economics and Management, 20(1), 43-62.

Zaenuri, Sudarmin, \& Utomo. (2017). Habituation Model of Impleenting Environmental Education In Elementary School. Journal of Indonesian Science Education. 